\title{
HOW MUCH ENTREPRENEURIAL CHARACTERISTICS MATTER IN STRATEGIC DECISION-MAKING?
}

\author{
${ }^{*} \mathrm{~F}$. Oben URU \\ *Sezer C. CALISKAN \\ *Özlem ATAM \\ *Mustafa AKSU \\ Haliç University,
}

\begin{abstract}
The main object of this paper is to examine the effects of entrepreneurial characteristics on the dimensions of strategic decision-making (SDM) process. Thus the research was conducted with 308 Turkish women entrepreneurs listed in The Union of Chambers and Commodity Exchanges of Turkey (TOBB)'s members in the form of local chambers of commerce and industry. As the results of analyses, women entrepreneurs' risk propensity have negative effect on their rational SDM process where as their risk propensity have positive effect on their formalized and centralized SDM process controlling environmental dynamism. Results show that women entrepreneurs with high need for achievement tend to make less rational SDs and centralize authority into the hands of themselves in dynamic environments. According to the results of analyses, women entrepreneurs with internal locus of control are more likely to make less rational decisions; favor more formalized processes and centralization. Results also show that optimistic women entrepreneurs make SDs based on subjective factors instead of rational SDs but follow more rule formalization in dynamic environments. According to findings, it can be suggested that women entrepreneurs' aggressive and proactive behavior lead them to make less rational decisions. Also they tend to follow more rule formalization in dynamic environments. Nevertheless, results also show women entrepreneurs with innovativeness tend to deal with novel and complex problems while adopting innovations. However, they make rational decisions while following rule formalization and do not delegate SDM authority. Furthermore, from the results of the analyses it is seen that entrepreneurial characteristics matter most in rational SDM process. This study's theoretical contribution is examination of effects of entrepreneurial characteristics on dimensions of SDM process in a comprehensive model; proposing new variables in the model and filling this gap in the research. Furthermore, this study's practical contribution is there is lack of research that consists of stated variables in our model conducted in small and medium size enterprises (SMEs) especially with women entrepreneurs. And finally, the methodological contribution of this study is investigation of predictors of SDM process in the context of entrepreneurial characteristics and business environment in Turkey, a developing country; it shows the external validity of factors influence on SDM process which were tested in Western developed countries.
\end{abstract}

Keywords: Women Entrepreneurs, Strategic Decision Making Process, Entrepreneurial Characteristics, SMEs; Business Environment.

\section{INTRODUCTION}

Strategic decision making (SDM) has long been a topic of great interest from a broad array of scholars in different fields. Some scholars focused on the content of SDM and identified key steps in the SDM process or the most important types or categories of SDM processes while others focused on the factors that influence the SDM processes (Bakker, Curpeu \& Vermeulen, 2007). In this context, SDM process is researched within three main perspectives: 'environmental determinism', 'firm characteristics and the resource-based view', 'strategic choice'. According to environmental determinism, strategic decisions and processes are adaptations to external opportunities, threats, constraints and other features of the environment (Papadakis \& Barwise, 1996). This perspective mainly addresses the question of how environmental factors (e.g. dynamism, hostility) influence SDM processes (Papadakis, Lioukas \& Chambers, 1998; Fredrickson, 1994; Eisenhardt, 1989; Judge \& Miller, 1991). The 'firm characteristics and the resource-based view' emphasizes factors internal to the firm such as its size, ownership, performance and systems resources and these factors constrain strategic decisions. (Papadakis \& Barwise, 2002). The 'strategic choice' perspective emphasizes the role and characteristics of decision makers and contends that SDM processes reflect the idiosyncrasies of key decision 
makers in light of 'upper echelons' or 'top managers' (Child, 1972; Hambrick \& Mason, 1984; Miller \& Toulouse, 1986; Papadakis \& Barwise, 1996; 2002). Among these, 'strategic choice' perspective has attracted much theoretical and empirical attention as there is a wealth of empirical research examining the relationship between top managers, their characteristics and organizational variables, (e.g. firm performance, innovation) SDM (Bantel \& Jackson, 1989; Hannan \& Freeman, 1977; Haleblian \& Finkelstein, 1993; Norburn \& Birley, 1988; Eisenhardt \& Schoonhoven, 1990; Smith et al., 1994; Rajagopalan, Rasheed \& Datta, 1993; Lewin \& Stephens, 1994; Miller \& Toulouse, 1986; Nahavandi \& Malekzadeh, 1993; Papadakis \& Barwise, 1996; 2002; Papadakis, Lioukas \& Chambers, 1998; Papadakis, 2006; Hitt \& Tyler, 1991; Stein, 1980; Lieberson \& O’Connor, 1972; Lyles \& Mitroff, 1980; Balta, Woods \& Dickson, 2010). However these studies emphasize strategic decision-making process as a sequence of steps, phases or its dimensions mostly in large firms. Surprisingly, little is known about the decision-making process within small and medium sized enterprises (SMEs). Strategic decisions in SMEs are made by individuals who also bear the ultimate responsibility for their decisions. This increases the relevance of the factors related to the decision-maker for the decision-making process. Strategic decisions made by small and medium sized business entrepreneurs form the heart of entrepreneurship and can therefore be considered as essential for the dynamics in the economy. Studies on the entrepreneurs and their strategic decision-making process will enrich the knowledge of mechanisms that drive SMEs to participate in the economy life of the state, contributing to growth and prosperity for society. Research show that the importance of strategic decision-making process in SMEs (Ivanova \& Gibcus, 2003; Gibcus, Vermeulen \& Jong, 2006; Gibcus \& Hoesel, 2004). But some debate exists regarding the factors leading to strategic decision-making process in SMEs. Theoretical studies focus on personality traits and/or cognitive biases of entrepreneurs (e.g. need for achievement, locus of control, optimism, risk propensity, innovativeness) and business environment in entrepreneurial SDM (Bakker, Curpeu \& Vermeulen, 2007; Vermeulen \& Curpeu, 2008; Brandstatter, 2010). Furthermore, most of the studies stress consequences of SDM process in SMEs. On the other hand, research in SMEs focusing on characterization of the SDM on dimensions (e.g. rationality, centralization, formalization, etc.) which allows examining possible interrelationships with environmental, contextual and other factors is not met. From the literature review, it is seen that there is lack of empirical research about the relationship between entrepreneurial characteristics and SDM process dimensions in SMEs. Given the lack of academic research about this topic, the objective of this study is to examine the effects of entrepreneurial characteristics on the dimensions of SDM process, focusing on women entrepreneurs in Turkey. In other words, this study explores main question: "How much entrepreneurial characteristics influence the process of making strategic decisions in dynamic environments?". For purposes of this study, first, prior theories and research focusing on entrepreneurial characteristics and SDM process dimensions are reviewed. Second, research hypotheses are developed and research model is presented. Third, discussion of the methods and findings are explained in the light of the research conducted to women entrepreneurs in Turkey. Finally, discussion about the research results is stated expressly.

\section{THEORETICAL BACKGROUND AND HYPOTHESES}

\section{Entrepreneurial Characteristics}

During the past two decades entrepreneurship has become a very active field of research in various social science disciplines and a prominent concern of economic policy. Adaptation of economic systems to changing conditions, innovation of products and services, creation of jobs, and economic growth is assumed to be very much dependent on the readiness and willingness of people to start an independent privately owned business and on the founders' skills and efforts to run it successfully (Brandstätter, 2010). Literature pointed to the importance of the entrepreneur for economic development, looking for personality traits uniquely characteristics of entrepreneurs was occasionally the topic of research. In addition, till now many of the research show entrepreneurs' characteristics are significantly different than non-entrepreneurs (McClelland, 1961; Brockhaus, 1980; Schere 1982; Low \& MacMillan, 1988). But still debate exits regarding the characteristics of entrepreneurs. Table 1 summarizes the entrepreneurial characteristics studied by the researchers. As it is seen from this table, different authors proposed different entrepreneurial characteristics. Among these characteristics, in this study entrepreneurs' risk propensity, need for achievement, locus of control, optimism, competitiveness and innovativeness are taken as basis because these are the most cited ones in theoretical studies. 
Table 1. Psychological and Cognitive Characteristics of Entrepreneurs

\begin{tabular}{|c|c|c|}
\hline Author & $\begin{array}{c}\text { Yea } \\
\mathbf{r}\end{array}$ & Characteristic(s) \\
\hline Bandura & 1986 & self-efficacy \\
\hline Baron & 1998 & $\begin{array}{l}\text { planning fallacy, attributional styles, escalation of } \\
\text { commitment, affect infusion }\end{array}$ \\
\hline Bazerman & 1999 & human cognition \\
\hline Brockhaus & 1980 & risk propensity \\
\hline Busenitz and Barney & 1997 & overconfidence \\
\hline Chen, Greene and Crick & 1998 & self-efficacy \\
\hline Cooper, Wood and Dunkelberg & 1988 & $\begin{array}{l}\text { growth oriented, independence oriented, craftsman } \\
\text { oriented, optimistic }\end{array}$ \\
\hline Hofstede & 1980 & $\begin{array}{l}\text { individualism, initiative taking, achievement moti- } \\
\text { vation }\end{array}$ \\
\hline Hornaday and Aboud & 1971 & $\begin{array}{l}\text { need for achievement, autonomy, aggression, } \\
\text { power, recognition, innovative/ independent }\end{array}$ \\
\hline Khatri and $\mathrm{Ng}$ & 2000 & intuitive decision-making \\
\hline Koen, Markman, Baron and Reilly & 2000 & misjudgement, cognitive biases \\
\hline Levander and Raccuia & 2001 & attention, self-confidence \\
\hline Low and Macmillan & 1988 & entrepreneurial cognitive biases \\
\hline Lyon, Lumpkin and Dess & 2000 & aggression, pro-activeness, autonomy \\
\hline McCarthy, Schoorman and Cooper & 1993 & self-esteem, optimism \\
\hline McCelland & 1967 & risk taking, need for achievement \\
\hline $\begin{array}{l}\text { McGrath, MacMillan and Scheine- } \\
\text { berg }\end{array}$ & 1992 & individualism, optimism, risk taking \\
\hline Mintzberg and Westley & 2001 & intuitive decision-making \\
\hline Mullins and Forlani & 2000 & risk propensity, venture choice, perceptions of risk \\
\hline Palich and Bagby & 1995 & risk taking \\
\hline Schumpeter & 1934 & innovation, initiative \\
\hline Sexton and Bowman & 1985 & $\begin{array}{l}\text { energetic/ ambitious, positive reaction to setbacks, } \\
\text { optimistic, individualistic }\end{array}$ \\
\hline Shapero and Sokol & 1982 & entrepreneurial acts, need for achievement \\
\hline Shaver and Scott & 1991 & entrepreneurial acts, achievement motivation \\
\hline Shere & 1982 & risk taking \\
\hline Staw and Fox & 1977 & escalation of commitment \\
\hline Timmons & 1990 & $\begin{array}{l}\text { goal oriented, moderated risk taker, internal locus of } \\
\text { control, creativity/ innovation }\end{array}$ \\
\hline Zacharakis and Shepherd & 2001 & $\begin{array}{l}\text { entrepreneurial information processing, overconfi- } \\
\text { dence }\end{array}$ \\
\hline
\end{tabular}

Source: Ivanova and Gibcus, 2003.

\section{Risk propensity}

Risk propensity describes an individual's attitude toward risk; in other words it is a psychological disposition of individuals to show varying degrees of risk-taking or risk avoidance behavior (Papadakis, 1996, 1998). It is considered to be an important characteristic in predicting organizational processes and outcomes (Gupta 1984; Nahavandi \& Malekzadeh, 1993, Papadakis, 1996) as well as it is a crucial variable in management decision making (March \& Shapira, 1982). And in the literature, it is stated that individuals with high risk propensity is typical of people who made rapid and innovative decisions (Sashkin, 1988; Taylor \& Dunnette, 1974). Farther, research show an empirical support that the risks incarnated in entrepreneurial ventures (Mullins \& Forlani, 2000).

\section{Need for Achievement}

Need for achievement has been shown to have broad consequences for behaviour (Miller \& Droge, 1986; Halikias \&Panayotopoulou, 2003). Individuals with high need for achievement are dominated 
by a desire to influence and control the context in which they operate because they seemed to be ambitious, hard working, competitive, keen to improve their social standing, and they place high value on achievements (McCleland and Donald, 1961, Papadakis, 2006). In the literature it is stated that a significant psychological explanation of entrepreneurial acts is the need for achievement (Shapero \& Sokol, 1982; Brockhaus, 1980). Researchers found empirical support that the entrepreneurs are initially driven by 'push' factors and have the achievement motivation. From his/her prospective the main characteristic of the business initiators is the high need for achievement described as a preference for challenge, acceptance of personal responsibility for outcomes and innovativeness (Ivanova \& Gibcus, 2003).

\section{Locus of Control}

The concept of locus of control refers to a generalized belief that a person can or cannot control his or her own destiny and individuals are classified along a continuum from very internal to very external (Rotter, 1966). Those who ascribe control of events to themselves are said to have an internal locus of control and are referred to as 'internals'. People who attribute control to outside forces are said to have an external locus of control and are termed as 'externals' (Spector, 1992; Nwachukwu, 1995; Carver, 1977). Research notes almost three decades of research consistently shows that internals are alert, discover opportunities, and scrutinize their environment to find information needed to formulate the optimal approach to developing those opportunities (Ivanova \& Gibcus, 2003).

\section{Optimism}

From the literature review, it is seen that optimism implies "a general disposition to expect the best in all things". Optimistic thinking, reactions and feelings are frequently studied in psychology. Optimism is a common attribute cited in entrepreneurship research when describing entrepreneurial individuals. Palich and Bagby (1995) suggest that entrepreneurs operate by a unique set of cognitive processes, thereby supporting their optimism. Furthermore, the literature on entrepreneurial behavior suggests that entrepreneurs are likely to be optimistic and that they frequently make judgements based on subjective factors (Ivanova \& Gibcus, 2003; Cooper et al., 1988; McCarthy et al., 1993; Timmons, 1990). Unfortunately entrepreneurship research has not provided empirical evidence that demonstrates whether or not entrepreneurs are optimistic, levels of optimism among different entrepreneurs, and how optimism relates to decisions and learning experiences in new venture formation.

\section{Competitiveness}

Research focusing on entrepreneurial behaviour implies that entrepreneurs are individuals who tend to be aggressive and proactive thus entrepreneurs behave likely to competitive (Lyon et al., 2000). Bazerman (1999) noted that individuals with competitive behavior want to win while believing that their decisions will mean that others' welfare will be somehow less as a consequence.

\section{Innovativeness}

Entrepreneur's innovativeness is one of the specific domain factor that separates them from managers (Frese, 2009; Brandstätter, 2010). Joseph Schumpeter (1954) believed the entrepreneur is the innovator who implements change within markets. As such, the entrepreneur moves the market away from its equilibrium. Schumpeter's innovation is an outcome of new combinations. These new combinations are broad, including new goods, new methods of production, new markets, or new organizations that define economic development. Similarly to Schumpeter, Drucker (1985) defines entrepreneurship as an act of innovation that involves adding a new wealth-producing capacity to existing resources (Ivanova \& Gibcus, 2003).

\section{Strategic Decision Making Process Dimensions}

Strategic decisions are crucial to the viability of firms and are defined as "intentional choices or programmed responses about issues that materially affect the survival prospects, well-being and nature of the organization" (Schoemaker, 1993:107). They guide the organization into the future and shape its course (Gibcus, Vermeulen \& Jong, 2006). For more than 40 years, scholars in various academic disciplines have recognized the importance of strategic decisions, resulting in a broad variety of literature. As to noted author Papadakis $(1998,2006)$ research focusing on strategic decision-making (SDM) process can be classified as 1-models of decision-making behavior which explain SDM processes in terms of a number of decision-making models, i.e. rational, bureaucratic, incremental, political, avoidance, etc; 2- Identification of stages/steps in strategic decision-making processes and finally dimensions of strategic decision-making processes which attempts to adopt a set of decision dimen- 
sions in approaching strategic processes. Papadakis (2006) stated "....this stream contends that the decision-making process is far from being an iterative, well-defined and sequentially evolving set of activities. Thus, instead of using step-by-step models of SDM processes researchers create a number of dimensions describing generic attributes of the process." (p.370). In this context, most of the researchers (i.e. Lyles, 1987; Lyles \& Mitroff, 1980; Miller et al., 1988; Dean \& Sharfman, 1993; Dean et al., 1993; Bourgeois \& Eisenhardt, 1998; Hickson et al., 1986; Hough and White, 2003; Papadakis, 1996, 1998, 2006) indicated SDM process includes rationality/comprehensiveness, formalization/ standardization, and centralization dimensions. In this study, these 3 dimensions are taken as basis of SDM process characteristics.

\section{Rationality}

The degree of rationality has occupied a central role in the literature of SDM (Wilson, 2003). The concept has its roots back in classic economic theory (Dean \& Sharfman, 1993). According to the rational decision making model, actors have known and predetermined objectives and evaluate all possible consequences of their actions. Then, they gather all relevant information, develop alternatives plans of action and finally select the most optimal alternative (Eisenhardt \& Zbaracki, 1992). Although there is considerable research on the descriptive adequacy of the rational model of decision making, evidence of the relationship between rationality and decision maker's characteristics is very limited. On the other hand, many of the studies presented in the literature concentrate on decision-making practices in large firms. This may be less valid in small firms. Research show that small firms tend to be less rational in their decision-making processes (Rice \& Hamilton, 1979; Brouthers et al., 1998; Byers \& Slack, 2001). This is because firstly entrepreneurs face a more hostile or uncertain environment in their decision making activities thus they do not have access to extensive information sources. Secondly the entrepreneurial environment is dynamic and complex and in this environment it is believed that the rationality of strategic decision processes tends to be lower and entrepreneurs do not develop routines and often act on the basis of opportunism (Gibcus, Vermeulen \& Jong, 2006). On this account, more research focusing on rational decision making process and decision maker's characteristics needs to be done.

\section{Formalization}

Formalization concerns the extent to which organizational policies, rules, charts and plans are articulated explicitly and formally in SDM processes (Eisenhardt \& Bourgeois, 1988). The relationship between planning formalization, individual characteristics and organizational outcomes has been a subject of debate among researchers and no consensus has yet emerged in the literature. Namely, there is not much evidence for negative (e.g. Pearce Ii \& Robbins, 1987) or positive relationship (e.g. Robinson, Pearce Ii, Vozikis, \& Mescon, 1984; Robinson \& Pearce Ii, 1983) between these constructs.

\section{Hierarchical Centralization}

Centralization of decision-making is one of the most frequently used SDM process dimensions (Papadakis \& Barwise, 2002) in SDM process studies. It emphasizes the role of participation in decision-making process (Papadakis, 1998) and refers to the concentration of authority or decision-making power in decision-making process (Wally \& Baum, 1994). It is usually reflected by the level and relative amount of participation in decision-making in an organization (Hage, 1980; Wally \& Baum, 1994). In the literature, there are both benefits and drawbacks to centralization in decision-making. As for the benefits, centralization may boost decision speed because few people involve in a decision process reduce the chance of conflict, communication time for consensus building and need for consultation (Pfeffer, 1981). It also encourages decision-makers to be assertive, venturesome and proactive because they make a choice without many challenges from different opinions (Miller, 1987).

However, centralization may affect organizational process negatively. Namely, it may decrease the rationality of decision-making because involving few people reduces the cognitive pool and information sharing and thus decreases the possibilities for an analytical approach to and innovative ideas for problem solving (Miller, 1987; Smith et al., 2006; Ji, 2010). As a result, there is no uniform definition of agreement as to the degree of centralization/decentralization. Also, contextual conditions and natural cultural effect are largely ignored. In this case, empirical studies should be conducted to fill this gap.

Noted authors argue that these three dimensions constitute the external environment of the firm. These are dynamism, complexity and munificence (Dess \& Beard, 1984; Sharfman \& Dean, 1991; Miller, Ogilvie, \& Glick, 2006;). From the literature review, it is seen studies focusing on SDM mostly con- 
sidered the role of environmental dynamism especially on the process-performance relationship. $\boldsymbol{D} \boldsymbol{y}$ namism, which is defined as the amount and unpredictability of changes in customer and competitors actions (Dess \&Beard, 1984) is a major environmental challenge that SMEs change in modern turbulent times worldwide. For the purposes of this study, it is decided to focus and control environmental dynamism since its notably effect on SDM process. Namely, the role of environmental dynamism on the relationship between rational decision making and performance has received a great deal of empirical attention in the literature (Forbes, 2007). Fredrickson (1984) argue that there is a negative relationship between comprehensiveness in decision processes and firm economic performance in unstable environments, and a positive relationship in stable environments. The rationale behind this argument is that in stable environments information and data are more readily available and more time is available for the use of more comprehensive/rational processes (Mueller et al., 2007). Thus, comprehensiveness which requires a great amount of information in order to be effective will lead to decreased performance if used in dynamic industry conditions. In contrast to Fredrickson, there is a constantly growing stream of research which suggests the exact opposite argument. Bourgeois and Eisenhardt (1988) indicated that rational decision making processes are beneficial in turbulent, highvelocity environments. Thus, the need for rational and formalized decision processes is stronger in dynamic than in stable environments (Dean \& Sharfman, 1996).

\section{Entrepreneurial Characteristics and Strategic Decision Making Process Dimensions}

From the literature review, it is seen that the personal characteristics of the decision-maker influence the decisions taken. Thus, in small firms rationality is expected to be decreased due to the strong personal influence of the entrepreneur (Brothers et al., 1998). As to Gibcus, Vermeulen and de Jong (2006) entrepreneurs perceive and think about risk and they tend to generalize easier from limited experience and are often overconfident that they will succeed. Studies also show that the risk taking entrepreneurs may influence the process in the direction of faster, less rational decisions, be reluctant to delegate decision-making authority, generally operate more by intuition than by rational analysis, tend to implement centralized organization designs characterized by high control intensity and direct supervision in order to minimize uncertainty (Sashkin, 1988; Taylor \& Dunnette, 1974; Mullins \& Forlani, 2000). This suggests that risk prone entrepreneurs will follow centralized configurations in decision-making and less rule formalization.

Hence the relationship between entrepreneur's risk propensity and dimensions of SDM process is hypothesized as:

\section{$H_{1 a}$ : Entrepreneur's risk propensity will be negatively related to rationality. \\ $\mathrm{H}_{1 \mathrm{~b}}$ : Entrepreneur's risk propensity will be negatively related to formalization. \\ $\mathrm{H}_{1 \mathrm{c}}$ : Entrepreneur's risk propensity will be positively related to centralization.}

On the basis of the previous discussion about entrepreneur's strong personal influence and overconfident that they will succeed, decrease rationality (Brothers et al., 1998). In other words, their high need for achievement may lead to centralize authority into the hands of themselves while making less rational decisions (Miller \& Droge, 1986). Hence the following hypotheses are advanced:

$\mathbf{H}_{2 \mathrm{a}}$ : Entrepreneur's need for achievement will be negatively related to rationality.

$H_{2 b}$ : Entrepreneur's need for achievement will be positively related to centralization.

In decision-making it has been found that entrepreneurs with an internal locus of control are more likely to be self-confident, innovative, alert, discover opportunities, and scrutinize their environment to find information needed to formulate the optimal approach to developing those opportunities (Gibcus, Vermeulen \& de Jong, 2006; Ivanova \& Gibcus, 2003). In this context, entrepreneurs with an internal locus of control likely to make less rational decisions due to their overconfident and innovative behavior; favor more formalized processes and centralization. Based upon the above arguments, the following hypotheses are advanced:

$\mathrm{H}_{3 \mathrm{a}}$ : Entrepreneur's internal locus of control will be negatively related to rationality.

$\mathbf{H}_{3 b}$ : Entrepreneur's internal locus of control will be positively related to formalization.

$\mathrm{H}_{3 \mathrm{c}}$ : Entrepreneur's internal locus of control will be positively related to centralization. 
The literature on entrepreneurial behavior suggests that entrepreneurs are likely to be optimistic and that they frequently make judgements based on subjective factors (Cooper et al., 1988; McCarthy et al.,1993; Timmons, 1990). From this point of view, optimistic entrepreneurs may tend to make SDs based on subjective factors instead of rational SDs and likely to follow less rule formalization. Therefore;

$\mathrm{H}_{4 \mathrm{a}}$ : Entrepreneur's optimistic behavior will be negatively related to rationality.

$\mathbf{H}_{4 b}$ : Entrepreneur's optimistic behavior will be negatively related to formalization.

Studies focusing on entrepreneurs indicate that they behave likely to competitive due to their aggressive and proactive behavior (Lyon et al.,2000). In this context, they may likely to make less rational decisions and follow less rule formalization. Hence the following hypotheses are advanced:

\section{$H_{5 a}$ : Entrepreneur's competitiveness will be negatively related to rationality.}

$H_{5 b}$ : Entrepreneur's competitiveness will be negatively related to formalization.

Research show entrepreneurs have intention to adopt innovations (Marcati, Guido \& Peluso, 2008; Brandstätter, 2010). In addition it is stated that entrepreneurs with innovativeness tend to deal with novel and complex problems while adopting innovations. However, they make rational decisions while following rule formalization and do not delegate SDM authority especially in the investment decision-making process (Gibcus, Vermeulen \& de Jong, 2006). According to these arguments the following hypotheses are advanced:

$H_{5 a}$ : Entrepreneur's innovativeness will be positively related to rationality.

$\mathrm{H}_{5 \mathrm{~b}}$ : Entrepreneur's innovativeness will be positively related to formalization.

$\mathbf{H}_{5 \mathrm{c}}$ : Entrepreneur's innovativeness will be positively related to centralization.

The proposed model showing details of variables and the relationships is depicted in Figure 1.

Figure 1: Proposed Research Model

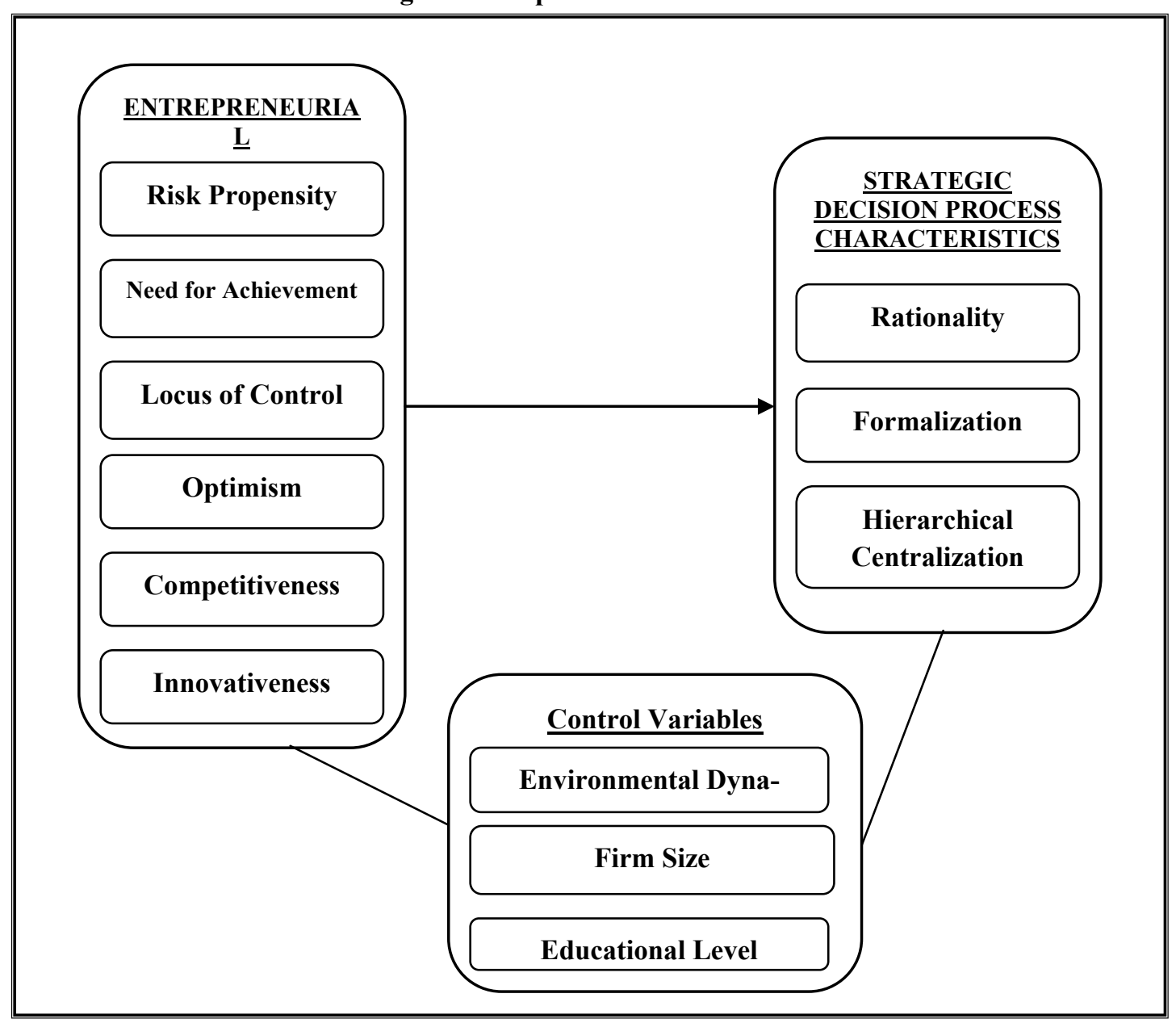




\section{METHODOLOGY}

\section{The Main Objective and Scope of the Research}

The main objective of this research is to examine the effects of entrepreneurial characteristics on the dimensions of SDM process. This research comprises Turkish women entrepreneurs listed in The Union of Chambers and Commodity Exchanges of Turkey (TOBB)'s members in the form of local chambers of commerce and industry. In this context, women entrepreneurs' opinions and perceptions are taken as base.

\section{Data Collection Method, Procedures and Type of Research}

This study was performed by explanatory research model. According to this, the effects of women entrepreneurs' characteristics on strategic decision process dimensions were explained and identified. The population of this study was composed of 80,000 Turkish women entrepreneurs listed in The Union of Chambers and Commodity Exchanges of Turkey (TOBB)'s members in the form of local chambers of commerce and industry.

Research sample consisted of 1000 Turkish women entrepreneurs chosen randomly listed in TOBB's members in the form of local chambers of commerce and industry. Data were collected through web-based structured questionnaires. In this research, 1000 Turkish women entrepreneurs are reached via e-mail and telephone to participate our web-based questionnaire. But some of the participants excused for not answering the questionnaires by reason of their workload. Hence 308 Turkish women entrepreneurs returned; thereby 308 women entrepreneurs' answers included in this research.

\section{Measures}

The questionnaire prepared for women entrepreneurs, consisted of 73 questions in 11 parts for measuring sample's demographic characteristics and variables proposed in the research model; thereby in this research 10 different scales were used. In the first part of the questionnaire, Risk propensity was measured with 7 five-point Likert-type scales employing an totally agree/disagree format. They were drawn from Meertens \& Lion's Risk Propensity Scale (2008). In the second part, to measure need for achievement Steers \& Braunsteins's (1976) and Heckert et al.'s (1999) 6 five-point Likert-type scales were used with options ranging from (1) 'strongly disagree (5) 'strongly agree'. In the third part, locus of control was measured with 10 items drawn from McDonald, Spears \& Parkers' scale (2004). In the fourth part, for measuring optimism 6 items with five-point Likert-type scale ranging from "strongly agree" to "strongly disagree" drawn from Scheier, Carver \& Bridges' Life Orientation Test-Revised (LOT-R) (1994) was used. In the fifth part, competitiveness was measured with McDonald, Spears \& Parkers' 6-item scale (2004). In the sixth part, innovativeness was measured with 11 five-point Likerttype scales employing an agree/disagree format. They were drawn from Hurt, Joseph \& Cooks' scale (1977) and McCroskey's (2006) scale. In the seventh part, for measuring rationality Dean \& Sharfmans' 5-item five-point likert type scale was used. In the eighth part, formalization was measured with Papadakis, Lioukas \& Chambers' (1998) 7-item scale. In the ninth part, for measuring hierarchical centralization Wally \& Baums' 5-item five-point likert type scale was used. In the tenth part, our proposed model's first control variable Environmental dynamism was measured with Miller \& Friesens' 5-item five-point Likert-type scale (1988). And finally in the last part, demographic questions for measuring descriptives and other control variables such as firm size and educational level were asked. Firm size was controlled through the natural logarithm of full-time employees (e.g. Fredrickson, 1984).

\section{Analysis}

In the direction of purpose of the study, following statistical analysis were performed using SPSS 19.0 Statistical Package and LISREL 8.54. First, for measuring participants' demographic characteristics frequency analyses were done. Second, reliability analyses using Cronbach's Alpha were performed towards the determination of internal consistencies of the scales. Also in this step, content validity and then construct validity were performed. For testing construct validity, Exploratory Factor Analysis (EFA) and Confirmatory Factor Analysis (CFA) were applied to determine whether the adapted forms of scales had valid factor structures. In this study EFA using principal components method and varimax rotation was performed to examine the factor structures of the scales according to the data ob- 
tained from the Turkish participants and CFA was applied to confirm the original scales structures in Turkish culture. In CFA, for models with good fit, chi-square $\left(X^{2}\right)$ normalized by degrees of freedom $\left(X^{2} / \mathrm{df}\right)$ should not exceed five. Among the absolute fit measures used to evaluate the model are; $X^{2}$ statistics divided by its degrees of freedom, goodness-of-fit index (GFI; Jöreskog \& Sörbom, 1993), Adjusted Goodness of Fit Index (AGFI; Hair et al., 2006), Comparative Fit Index (CFI; Bentler, 1990), Normed Fit Index (NFI; Browne \& Cudeck, 1992), Relative Fit Index (RFI; Browne \& Cudeck, 1992), Root Mean Square Error of Approximation (RMSEA; Steiger, 1990) Standardized Root Mean Square Residual (SRMR, Jöreskog \& Sörbom, 1993). Fit Indexes such as GFI, AGFI, CFI, NFI and RFI were evaluated with the traditional cutoff value of .90. In addition, good fit is achieved with RMSEA and SRMR values of .05 or less; acceptable fit, with values between .05 and .10; poor fit, with values larger than .10 (Steiger, 1990; Jöreskog \& Sörbom, 1993; Browne \& Cudeck, 1992).

Third, to determine means, standard deviations and to understand correlations among all factors came out in the factor analysis, descriptive statistics were performed. And last, testing of the effects of the independent variables upon the dependent variables multiple regression analyses and hierarchical regression analyses were conducted.

\section{FINDINGS}

\section{Frequency Analysis}

Demographic questions were analyzed according to frequency. In Table 2, frequency analysis shows the sample of the questionnaire.

Table 2. Sample's Demographic Characteristics

\begin{tabular}{|c|c|c|c|}
\hline $\begin{array}{c}\text { DEMOGRAPHIC } \\
\text { CHARACTERISTICS }\end{array}$ & $\begin{array}{l}\text { CATEGORIES OF } \\
\text { VARIABLES }\end{array}$ & f & $\%$ \\
\hline \multirow{4}{*}{ Age } & $27-37$ & 118 & 38,3 \\
\hline & $38-47$ & 130 & 42,2 \\
\hline & $48-57$ & 45 & 14,6 \\
\hline & above 57 & 15 & 4,9 \\
\hline \multirow{3}{*}{ Marital Status } & Single (Unmarried) & 67 & 21,8 \\
\hline & Married & 215 & 69,8 \\
\hline & Widowed & 26 & 8,4 \\
\hline \multirow{7}{*}{ Educational Level } & Elementary School & 3 & 1 \\
\hline & Secondary School & 16 & 5,2 \\
\hline & High School & 139 & 45,1 \\
\hline & Vocational School & 21 & 6,8 \\
\hline & University & 103 & 33,4 \\
\hline & Master's & 12 & 3,9 \\
\hline & Doctorate & 14 & 4,5 \\
\hline \multirow{5}{*}{ Firm Age } & $5-10$ & 81 & 26,3 \\
\hline & $10,1-15$ & 103 & 33,4 \\
\hline & $15,1-20$ & 45 & 14,6 \\
\hline & $20,1-25$ & 42 & 13,6 \\
\hline & above 25 & 37 & 12 \\
\hline \multirow{6}{*}{ Number of Employees } & $0-25$ employees & 199 & 64,6 \\
\hline & 26-50 employees & 17 & 5,5 \\
\hline & 51-75 employees & 14 & 4,5 \\
\hline & 76-100 employees & 13 & 4,2 \\
\hline & 101-125 employees & 17 & 5,5 \\
\hline & 126 and more employees & 48 & 15,6 \\
\hline
\end{tabular}

Note. $N=308$ 


\section{Factor and Reliability Analyses}

Content validity of the survey instrument was established through the adoption of validated instruments by other researchers in the literature (Straub, 1989). During the translation process, by local meeting with professionals content validity was established. And Turkish final versions of the scales were used to measure each construct.

Risk Propensity Scale (RPS). Internal consistency reliability to test unidimensionality was assessed by Cronbach's alpha. As a result of Cronbach's reliability analysis performed for RPS, 1 item decreased the reliability was eliminated and the scale had reliability as Cronbach's á $=.887$. Therefore EFA repeated. After EFA was performed, 1 factor which Eigenvalue $\geq 1$ obtained consisting of 6 items $\left(\mathrm{KMO}=0,827, X_{\text {Bartlett test }}^{2}(21)=1428,369 p=0,000\right)$. Total variance explained was $64,330 \%$. The results of CFA indicated that the model was well fit and Chi-Square value $\left(X^{2}\right)=79.88, \mathrm{~N}=308, \mathrm{df}=19$, $\mathrm{p}<.000, X^{2} / \mathrm{df}=4.20$ ) which was calculated for the adaptation of the model was found to be significant. The goodness of fit index values of model were $\mathrm{GFI}=0.89$, AGFI $=0.90, \mathrm{CFI}=0.91, \mathrm{NFI}=0.90$, $\mathrm{RFI}=0.92, \mathrm{RMSEA}=0.072, \mathrm{SRMR}=0.046$. According to these values, it can be said that the structural model of RPS which consists of one factor was well fit to the Turkish culture.

Need for Achievement Scale (NACH). As a result of Cronbach's reliability analysis performed for $\mathrm{NACH}, 1$ item decreased the reliability was eliminated and the scale had reliability as Cronbach's $\mathrm{a}=.819$. Therefore EFA repeated. After EFA was performed, 1 factor which Eigenvalue $\geq 1$ obtained consisting of 5 items $\left(\mathrm{KMO}=0,826, X_{\text {Bartlett test }}^{2}(10)=888,507 p=0,000\right)$. Total variance explained was $68,143 \%$. The results of CFA indicated that the model had acceptable fit and Chi-Square value $\left(X^{2}\right)$ $\left.=68.65, \mathrm{~N}=308, \mathrm{df}=16, \mathrm{p}<.000, X^{2} / \mathrm{df}=4.29\right)$ which was calculated for the adaptation of the model was found to be significant. The goodness of fit index values of model were GFI $=0.88$, AGFI $=0.89$, $\mathrm{CFI}=0.90, \mathrm{NFI}=0.90, \mathrm{RFI}=0.91, \mathrm{RMSEA}=0.083, \mathrm{SRMR}=0.077$. According to these values, it can be said that the structural model of NACH which consists of one factor had acceptable fit for the Turkish culture.

Locus of Control Scale (LOCON). As a result of Cronbach's reliability analysis performed for LOCON, the scale had a strong reliability (Cronbach's á $=.913$ ). As a result of EFA performed for LOCON, 1 factor which Eigenvalue $\geq 1$ obtained consisting of 10 items $\left(\mathrm{KMO}=0,839, X_{\text {Bartlett test }}^{2}(45)\right.$ $=2095,232 p=0,000)$. Total variance explained was 77,024\%. The results of CFA indicated that the model was well fit and Chi-Square value $\left.\left(X^{2}\right)=128.67, \mathrm{~N}=308, \mathrm{df}=33, \mathrm{p}<.000, X^{2} / \mathrm{df}=3.89\right)$ which was calculated for the adaptation of the model was found to be significant. The goodness of fit index values of model were $\mathrm{GFI}=0.91, \mathrm{AGFI}=0.92, \mathrm{CFI}=0.91, \mathrm{NFI}=0.92, \mathrm{RFI}=0.91$, RMSEA $=0.061$, $\mathrm{SRMR}=0.039$. According to these values, it can be said that the structural model of LOCON which consists of one factor was well fit to the Turkish culture.

Optimism Scale (OS). As a result of Cronbach's reliability analysis performed for OS, the scale had reliability as Cronbach's á $=.891$. As a result of EFA performed for OS, 1 factor which Eigenvalue $\geq 1$ obtained consisting of 6 items $\left(\mathrm{KMO}=0,815, X^{2}{ }_{\text {Bartlett test }}(15)=508,139 p=0,000\right)$. Total variance explained was $69,562 \%$. The results of CFA indicated that the model had acceptable fit and Chi-Square value $\left.\left(X^{2}\right)=38.41, \mathrm{~N}=308, \mathrm{df}=10, \mathrm{p}<.000, X^{2} / \mathrm{df}=3.841\right)$ which was calculated for the adaptation of the model was found to be significant. The goodness of fit index values of model were GFI $=0.89$, AGFI $=0.90, \mathrm{CFI}=0.91, \mathrm{NFI}=0.90, \mathrm{RFI}=0.90, \mathrm{RMSEA}=0.065, \mathrm{SRMR}=0.057$. According to these values, it can be said that the structural model of OS which consists of one factor had acceptable fit for the Turkish culture.

Competitiveness Scale (COMP). As a result of Cronbach's reliability analysis performed for COMP, the scale had reliability as Cronbach's á $=.857$. As a result of EFA performed for COMP, 1 factor which Eigenvalue $\geq 1$ obtained consisting of 6 items $\left(\mathrm{KMO}=0,830, X^{2}{ }_{\text {Bartlett test }}(15)=859,304 p=0,000\right)$. Total variance explained was $69,045 \%$. The results of CFA indicated that the model was well fit and Chi-Square value $\left.\left(X^{2}\right)=57.33, \mathrm{~N}=308, \mathrm{df}=12, \mathrm{p}<.000, X^{2} / \mathrm{df}=4.77\right)$ which was calculated for the adaptation of the model was found to be significant. The goodness of fit index values of model were $\mathrm{GFI}=0.90, \mathrm{AGFI}=0.91, \mathrm{CFI}=0.91, \mathrm{NFI}=0.90, \mathrm{RFI}=0.90, \mathrm{RMSEA}=0.051, \mathrm{SRMR}=0.049$. According to these values, it can be said that the structural model of COMP which consists of one factor was well fit to the Turkish culture.

Innovativeness Scale (INNOV). As a result of Cronbach's reliability analysis performed for INNOV, the scale had a strong reliability (Cronbach's á $=.920$ ). As a result of EFA performed for INNOV, 1 factor which Eigenvalue $\geq 1$ obtained consisting of 11 items $\left(\mathrm{KMO}=0,857, X^{2}{ }_{\text {Bartlett test }}(55)=2443,879\right.$ 
$p=0,000$ ). Total variance explained was $75,825 \%$. The results of CFA indicated that the model was well fit and Chi-Square value $\left.\left(X^{2}\right)=182.56 \mathrm{~N}=308, \mathrm{df}=40, \mathrm{p}<.000, X^{2} / \mathrm{df}=4.564\right)$ which was calculated for the adaptation of the model was found to be significant. The goodness of fit index values of model were $\mathrm{GFI}=0.90, \mathrm{AGFI}=0.92, \mathrm{CFI}=0.90, \mathrm{NFI}=0.91, \mathrm{RFI}=0.92, \mathrm{RMSEA}=0.041, \mathrm{SRMR}=0.032$. According to these values, it can be said that the structural model of INNOV which consists of one factor was well fit to the Turkish culture.

Rationality Scale (RAS). As a result of Cronbach's reliability analysis performed for RAS, the scale had a strong reliability (Cronbach's á= .903). As a result of EFA performed for RAS, 1 factor which Eigenvalue $\geq 1$ obtained consisting of 5 items $\left(\mathrm{KMO}=0,870, X_{\text {Bartlett test }}^{2}(29)=1067,298 p=0,000\right)$. Total variance explained was $72,115 \%$. The results of CFA indicated that the model was well fit and ChiSquare value $\left.\left(X^{2}\right)=93.76 \mathrm{~N}=308, \mathrm{df}=28, \mathrm{p}<.000, X^{2} / \mathrm{df}=3.348\right)$ which was calculated for the adaptation of the model was found to be significant. The goodness of fit index values of model were GFI $=0.90$, $\mathrm{AGFI}=0.91, \mathrm{CFI}=0.91, \mathrm{NFI}=0.90, \mathrm{RFI}=0.91, \mathrm{RMSEA}=0.042, \mathrm{SRMR}=0.039$. According to these values, it can be said that the structural model of RAS which consists of one factor was well fit to the Turkish culture.

Formalization Scale (FORM). As a result of Cronbach's reliability analysis performed for FORM, the scale had a strong reliability (Cronbach's á $=.911$ ). As a result of EFA performed for FORM, 1 factor which Eigenvalue $\geq 1$ obtained consisting of 7 items $\left(\mathrm{KMO}=0,889, X^{2}{ }_{\text {Bartlett test }}(21)=1394,409\right.$ $p=0,000$ ). Total variance explained was $66,171 \%$. The results of CFA indicated that the model had acceptable fit and Chi-Square value $\left.\left(X^{2}\right)=101.34 \mathrm{~N}=308, \mathrm{df}=22, \mathrm{p}<.000, X^{2} / \mathrm{df}=4.606\right)$ which was calculated for the adaptation of the model was found to be significant. The goodness of fit index values of model were $\mathrm{GFI}=0.89$, AGFI $=0.90, \mathrm{CFI}=0.90, \mathrm{NFI}=0.90, \mathrm{RFI}=0.91$, RMSEA $=0.073$, $\mathrm{SRMR}=0.058$. According to these values, it can be said that the structural model of FORM which consists of one factor had acceptable fit to the Turkish culture.

Hierarchical Centralization Scale (HCENT). As a result of Cronbach's reliability analysis performed for HCENT, 1 item decreased the reliability was eliminated and the scale had reliability as Cronbach's $\mathrm{a}=.794$. Therefore EFA repeated. After EFA was performed, 1 factor which Eigenvalue $\geq 1$ obtained consisting of 4 items $\left(\mathrm{KMO}=0,807, X^{2}\right.$ Bartlett test $\left.(9)=641,928 p=0,000\right)$. Total variance explained was $62,334 \%$. The results of CFA indicated that the model had acceptable fit and Chi-Square value $\left(X^{2}\right)$ $=62.51 \mathrm{~N}=308, \mathrm{df}=18, \mathrm{p}<.000, X^{2} / \mathrm{df}=3.472$ ) which was calculated for the adaptation of the model was found to be significant. The goodness of fit index values of model were GFI $=0.88$, AGFI $=0.89$, $\mathrm{CFI}=0.90, \mathrm{NFI}=0.89, \mathrm{RFI}=0.90, \mathrm{RMSEA}=0.096, \mathrm{SRMR}=0.077$. According to these values, it can be said that the structural model of HCENT which consists of one factor had acceptable fit to the Turkish culture.

Environmental Dynamism Scale (EDYN). As a result of Cronbach's reliability analysis performed for EDYN, the scale had reliability as Cronbach's á $=.773$. As a result of EFA performed for EDYN, 1 factor which Eigenvalue $\geq 1$ obtained consisting of 5 items $\left(\mathrm{KMO}=0,808, X^{2}{ }_{\text {Bartlett test }}(10)=530,525\right.$ $p=0,000$ ). Total variance explained was $63,709 \%$. The results of CFA indicated that the model was had acceptable fit and Chi-Square value $\left(X^{2}\right)=42.14, \mathrm{~N}=308, \mathrm{df}=9, \mathrm{p}<.000, X^{2} / \mathrm{df}=4.682$ ) which was calculated for the adaptation of the model was found to be significant. The goodness of fit index values of model were $\mathrm{GFI}=0.88, \mathrm{AGFI}=0.89, \mathrm{CFI}=0.90, \mathrm{NFI}=0.89, \mathrm{RFI}=0.90, \mathrm{RMSEA}=0.082$, $\mathrm{SRMR}=0.070$. According to these values, it can be said that the structural model of $\mathrm{E}$ which consists of one factor had acceptable fit to the Turkish culture.

All of the factor scores in the research were calculated via averaging. 


\section{Descriptive Statistics}

Table 3. Means, Standard Deviations, and Correlations ${ }^{a}$

\begin{tabular}{|c|c|c|c|c|c|c|c|c|c|c|c|c|c|c|}
\hline Variables & Mean & s.d. & 1 & 2 & 3 & 4 & 5 & 6 & 7 & 8 & 9 & 10 & 11 & 12 \\
\hline 1. Risk Propensity & 4,55 & 0,51 & 1 & & & & & & & & & & & \\
\hline $\begin{array}{l}\text { 2. Need for } \\
\text { Achievement }\end{array}$ & 4,61 & 0,38 & $.600 * *$ & 1 & & & & & & & & & & \\
\hline 3. Locus of Control & 4,52 & 0,49 & $.650^{* *}$ & $.642 * *$ & 1 & & & & & & & & & \\
\hline 4. Optimism & 4,58 & 0,41 & $.627^{* *}$ & $.697 * *$ & $.723 * *$ & 1 & & & & & & & & \\
\hline 5. Competitiveness & 4,58 & 0,45 & $.726^{* *}$ & $.723^{* *}$ & $.775^{* *}$ & $.658^{* *}$ & 1 & & & & & & & \\
\hline 6. Innovativeness & 4,67 & 0,43 & $.554 * *$ & $.370^{* *}$ & $.576^{* *}$ & $.505^{* * *}$ & $.629 * *$ & 1 & & & & & & \\
\hline 7. Rationality & 4,37 & 0,50 & -.054 & $-.408^{* *}$ & -.111 & $-.255^{* *}$ & -.080 & $.290^{* *}$ & 1 & & & & & \\
\hline 8. Formalization & 4,30 & 0,49 & $.341 * *$ & $.177^{* *}$ & $.319^{* *}$ & $.263^{* * *}$ & $.384 * *$ & $.241^{* *}$ & $.493 * *$ & 1 & & & & \\
\hline $\begin{array}{l}\text { 9. Hierarchical } \\
\text { Centralization }\end{array}$ & 4,74 & 0,32 & $.232 * *$ & $.190^{* *}$ & $.211^{* *}$ & $.150^{* *}$ & $.129^{*}$ & $.374^{* *}$ & -.108 & $-.151^{* *}$ & 1 & & & \\
\hline $\begin{array}{l}\text { 10. Environmental } \\
\text { Dynamism }\end{array}$ & 4,20 & 0,50 &, $447 * *$ & .095 & $.403^{* *}$ & $.318^{* *}$ & $.389 * *$ & $.261^{* *}$ & $.384 * *$ & $.461^{* *}$ & -.088 & 1 & & \\
\hline 11. Educational Level ${ }^{\mathbf{b}}$ & 12,95 & 2,93 & -.032 & -.014 & -.070 & -.130 & -.138 & -316 & .132 & .426 & -.130 & .049 & 1 & \\
\hline 12. Firm Size ${ }^{c}$ & 56,71 & 69,71 & -.090 & -.167 & -.051 & -.149 & -.137 & -.240 & .084 & .136 & -.332 & .106 & .288 & 1 \\
\hline
\end{tabular}

${ }^{a} \mathrm{~N}=308$

${ }^{\text {b }}$ Education is measured in years completed in the schools.

${ }^{\mathbf{c}}$ Firm size is measured through the log of full-time employees.

$* \mathrm{p}<0.05 \quad * * \mathrm{p}<0.01$

Table 3 displays means, standard deviations, and correlations among all the variables. As it is seen, all variables except educational level and firm size have correlations. Therefore only environmental dynamism was taken as a control variable in the analysis (correlation with rationality and formalization).

\section{Regression Analyses}

To test research hypotheses, multiple regression analyses and hierarchical regression analyses were conducted. To test full model, separate regression models (hierarchical regression analysis) were applied for each SD process dimension. Hierarchical regression allows for an assessment of the incremental increase in the explained variance of a dependent variable that is explained by the successive addition of sets of independent variables where the variance explained by previously entered variables is partialled out (Cohen and Cohen 1983). In the full model, independent variables were introduced in two blocks. First, the control variables were introduced. The entrepreneurial characteristics followed in steps 2. Model F-tests of significance (Cohen and Cohen 1983) were used to assess the changes in $\mathrm{R}^{2}$ resulting from the addition of each new set of predictors. A significant change in $\mathrm{R}^{2}$ for step 2 (entrepreneurial characteristics), would indicate that these characteristics significantly influence the specific process dimension. According to the correlations among the independent variables exhibited in Table 2 (and in collinearity statistics VIF values $<10$ ), Multicollinearity was not a severe problem that would preclude interpretation of the regression analyses. Also it is determined that there is no autocorrelation since Durbin-Watson test statistics values were close to 2 . In this context, stepwise regression method was executed.

Hypothesis 1 suggested that entrepreneur's risk propensity would be negatively related to (a) rationality, (b) formalization and positively related to (c) centralization. Therefore, $\mathrm{H}_{1}$ was tested using multiple regression analysis (See Table 4, 5 \& 6). 
Table 4. Summary of Multiple Regression Analysis Predicting Relationship between Entrepreneur's Risk Propensity and Rationality

\begin{tabular}{llccccc}
\hline (Independent) & Variables & Adjusted R & F & F sig. & $\boldsymbol{\beta}$ & p \\
\hline $1^{\text {st }}$ Step: & Environmental Dynamism & .145 & 52.98 & .000 & .510 & .000 \\
$2^{\text {nd }}$ Step: & Entrepreneur's Risk Propensity & .206 & 40.81 & .000 & -.282 & .000 \\
\hline
\end{tabular}

Dependent Variable: Rationality

As exhibited in Table 4, entrepreneur's risk propensity was negatively related to rationality when environmental dynamism was controlled. Explanatory rate of the model that has 2 variables is .20. Therefore, the findings support $\mathbf{H}_{1 \mathrm{a}}$.

Table 5. Summary of Multiple Regression Analysis Predicting Relationship between Entrepreneur's Risk Propensity and Formalization

\begin{tabular}{llccccc}
\hline (Independent) & Variables & Adjusted R $^{2}$ & F & F sig. & $\boldsymbol{\beta}$ & p \\
\hline $1^{\text {st }}$ Step: & Environmental Dynamism & .210 & 82.75 & .000 & .386 & .000 \\
$2^{\text {nd }}$ Step: & Entrepreneur's Risk Propensity & .230 & 46.96 & .000 & .168 & .003 \\
\hline
\end{tabular}

Dependent Variable: Formalization

As exhibited in Table 4, entrepreneur's risk propensity was positively related to formalization when environmental dynamism was controlled. Explanatory rate of the model that has 2 variables is .23. Therefore, the findings do not support $\mathbf{H}_{1 \mathrm{~b}}$.

Table 6. Summary of Multiple Regression Analysis Predicting Relationship between Entrepreneur's Risk Propensity and Centralization

\begin{tabular}{llccccc}
\hline (Independent) & Variables & Adjusted R $^{\mathbf{2}}$ & $\mathbf{F}$ & $\mathbf{F}$ sig. & $\boldsymbol{\beta}$ & $\mathbf{p}$ \\
\hline $1^{\text {st }}$ Step: & Entrepreneur's Risk Propensity & .051 & 17.38 & .000 & .339 & .000 \\
$2^{\text {nd }}$ Step: & Environmental Dynamism & .094 & 16.86 & .000 & -.239 & .000 \\
\hline
\end{tabular}

Dependent Variable: Centralization

As exhibited in Table 4, entrepreneur's risk propensity was positively related to centralization when environmental dynamism was controlled. Explanatory rate of the model that has 2 variables is .09 . Therefore, the findings support $\mathbf{H}_{1 \mathbf{c}}$.

Hypothesis 2 suggested that entrepreneur's need for achievement would be negatively related to (a) rationality and positively related to (b) centralization. Therefore, $\mathrm{H}_{2}$ was tested using multiple regression analysis (See Table $7 \& 8$ ).

Table 7. Summary of Multiple Regression Analysis Predicting Relationship between Entrepreneur's Need for Achievement and Rationality

\begin{tabular}{llccccc}
\hline (Independent) & Variables & Adjusted $\mathbf{R}^{2}$ & $\mathbf{F}$ & F sig. & $\boldsymbol{\beta}$ & $\mathbf{p}$ \\
\hline $1^{\text {st }}$ Step: & Entrepreneur's Need for Achievement & .164 & 61.10 & .000 & -.449 & .000 \\
$2^{\text {nd }}$ Step: & Environmental Dynamism & .343 & 81.03 & .000 & .427 & .000 \\
\hline
\end{tabular}

Dependent Variable: Rationality

As exhibited in Table 7, entrepreneur's need for achievement was negatively related to rationality when environmental dynamism was controlled. Explanatory rate of the model that has 2 variables is .34. Therefore, the findings support $\mathbf{H}_{2 a}$.

Table 8. Summary of Multiple Regression Analysis Predicting Relationship between Entrepreneur's Need for Achievement and Centralization

\begin{tabular}{ccccccc}
\hline (Independent) & Variables & Adjusted R $^{2}$ & F & F sig. & $\boldsymbol{\beta}$ & $\mathbf{p}$ \\
\hline $1^{\text {st }}$ Step: $\quad$ Entrepreneur's Need for Achievement & .033 & 11.48 & .000 & .190 & .001 \\
\hline Dependent Variable: Centralization & & & & &
\end{tabular}


As exhibited in Table 8, entrepreneur's need for achievement was positively related to centralization when environmental dynamism was controlled. Explanatory rate of the model that has 1 variable is .03. Therefore, the findings support $\mathbf{H}_{2 b}$.

Hypothesis 3 suggested that entrepreneur's internal locus of control would be negatively related to (a) rationality, and positively related to (b) formalization, (c) centralization,. Therefore, $\mathrm{H}_{3}$ was tested using multiple regression analysis (See Table 9, $10 \& 11$ ).

Table 9. Summary of Multiple Regression Analysis Predicting Relationship between

\begin{tabular}{|c|c|c|c|c|c|c|}
\hline (Independent) & Variables & Adjusted $\mathbf{R}^{2}$ & $\mathbf{F}$ & F sig. & $\boldsymbol{\beta}$ & $\mathbf{p}$ \\
\hline $1^{\text {st }}$ Step: & Environmental Dynamism & .145 & 52.98 & .000 & .512 & .000 \\
\hline $2^{\text {nd }}$ Step: & Entrepreneur's Internal Locus of Control & .227 & 46.12 & .000 & -.318 & .000 \\
\hline
\end{tabular}

\section{Entrepreneur's Internal Locus of Control and Rationality}

Dependent Variable: Rationality

As exhibited in Table 9, entrepreneur's internal locus of control was negatively related to rationality when environmental dynamism was controlled. Explanatory rate of the model that has 2 variables is .22. Therefore, the findings support $\mathbf{H}_{3 \mathbf{a}}$.

Table 10. Summary of Multiple Regression Analysis Predicting Relationship between Entrepreneur's Internal Locus of Control and Formalization

\begin{tabular}{llccccc}
\hline (Independent) & Variables & Adjusted R $^{\mathbf{2}}$ & F & F sig. & $\boldsymbol{\beta}$ & $\mathbf{p}$ \\
\hline $1^{\text {st }}$ Step: & Environmental Dynamism & .210 & 82.75 & .000 & .397 & .000 \\
$2^{\text {nd }}$ Step: & Entrepreneur's Internal Locus of Control & .229 & 46.60 & .000 & .159 & .004 \\
\hline
\end{tabular}

Dependent Variable: Formalization

As exhibited in Table 10, entrepreneur's internal locus of control was positively related to formalization when environmental dynamism was controlled. Explanatory rate of the model that has 2 variables is .22. Therefore, the findings support $\mathbf{H}_{3 \mathbf{b}}$.

Table 11. Summary of Multiple Regression Analysis Predicting Relationship between Entrepreneur's Internal Locus of Control and Centralization

\begin{tabular}{|c|c|c|c|c|c|c|}
\hline (Independent & Variables & Adjusted $\mathbf{R}^{2}$ & $\mathbf{F}$ & F sig. & $\boldsymbol{\beta}$ & $\mathbf{p}$ \\
\hline $1^{\text {st }}$ Step: & Entrepreneur's Internal Locus of Control & .041 & 14.22 & .000 & .294 & .000 \\
\hline $2^{\text {nd }}$ Step: & Environmental Dynamism & .074 & 13.27 & .000 & -.206 & .001 \\
\hline
\end{tabular}

Dependent Variable: Centralization

As exhibited in Table 11, entrepreneur's internal locus of control was positively related to centralization when environmental dynamism was controlled. Explanatory rate of the model that has 2 variables is .07. Therefore, the findings support $\mathbf{H}_{3 \mathrm{c}}$.

Hypothesis 4 suggested that entrepreneur's optimistic behavior would be negatively related to (a) rationality, and (b) formalization. Therefore, $\mathrm{H}_{4}$ was tested using multiple regression analysis (See Table 12 \& 13).

Table 12. Summary of Multiple Regression Analysis Predicting Relationship between Entrepreneur's Optimistic Behavior and Rationality

Dependent Variable: Rationality

\begin{tabular}{llccccc}
\hline (Independent) & Variables & Adjusted R & F & F sig. & $\boldsymbol{\beta}$ & $\mathbf{p}$ \\
\hline $1^{\text {st }}$ Step: & Environmental Dynamism & .145 & 52.98 & .000 & .518 & .000 \\
$2^{\text {nd }}$ Step: & Entrepreneur's Optimistic Behavior & .301 & 67.13 & .000 & -.419 & .000 \\
\hline
\end{tabular}


As exhibited in Table 12, entrepreneur's optimistic behavior was negatively related to rationality when environmental dynamism was controlled. Explanatory rate of the model that has 2 variables is .30. Therefore, the findings support $\mathbf{H}_{4 \mathbf{a}}$.

Table 13. Summary of Multiple Regression Analysis Predicting Relationship between Entrepreneur's Optimistic Behavior and Formalization

\begin{tabular}{llccccc}
\hline (Independent) & Variables & Adjusted R $^{2}$ & $\mathbf{F}$ & F sig. & $\boldsymbol{\beta}$ & $\mathbf{p}$ \\
\hline $1^{\text {st }}$ Step: & Environmental Dynamism & .210 & 82.75 & .000 & .420 & .000 \\
$2^{\text {nd }}$ Step: & Entrepreneur's Optimistic Behavior & .223 & 45 & .000 & .129 & .016 \\
\hline
\end{tabular}

Dependent Variable: Formalization

As exhibited in Table 13, entrepreneur's optimistic behavior was positively related to formalization when environmental dynamism was controlled. Explanatory rate of the model that has 2 variables is .22. Therefore, the findings do not support $\mathbf{H}_{4 \mathbf{b}}$.

Hypothesis $\mathbf{5}$ suggested that entrepreneur's competitiveness would be negatively related to (a) rationality, and (b) formalization. Therefore, $\mathrm{H}_{5}$ was tested using multiple regression analysis (See Table 14 $\& 15)$

Table 14. Summary of Multiple Regression Analysis Predicting Relationship between Entrepreneur's Competitiveness and Rationality

\begin{tabular}{llccccc}
\hline (Independent) & Variables & Adjusted $^{2}$ & $\mathbf{F}$ & F sig. & $\boldsymbol{\beta}$ & p \\
\hline $1^{\text {st }}$ Step: & Environmental Dynamism & .145 & 52.98 & .000 & .490 & .000 \\
$2^{\text {nd }}$ Step: & Entrepreneur's Competitiveness & .205 & 40.50 & .000 & -.271 & .000 \\
\hline
\end{tabular}

Dependent Variable: Rationality

As exhibited in Table 14, entrepreneur's competitiveness was negatively related to rationality when environmental dynamism was controlled. Explanatory rate of the model that has 2 variables is .20 . Therefore, the findings support $\mathbf{H}_{5 \mathbf{a}}$.

Table 15. Summary of Multiple Regression Analysis Predicting Relationship between Entrepreneur's Competitiveness and Formalization

\begin{tabular}{llccccc}
\hline (Independent) & Variables & Adjusted R $^{\mathbf{2}}$ & $\mathbf{F}$ & $\mathbf{F}$ sig. & $\boldsymbol{\beta}$ & $\mathbf{p}$ \\
\hline $1^{\text {st }}$ Step: & Environmental Dynamism & .210 & 82.75 & .000 & .367 & .000 \\
$2^{\text {nd }}$ Step: & Entrepreneur's Competitiveness & .257 & 54.22 & .000 & .241 & .000 \\
\hline
\end{tabular}

Dependent Variable: Formalization

As exhibited in Table 15, entrepreneur's competitiveness was positively related to formalization when environmental dynamism was controlled. Explanatory rate of the model that has 2 variables is .25 . Therefore, the findings do not support $\mathbf{H}_{5 \mathbf{b}}$.

Hypothesis 6 suggested that entrepreneur's innovativeness would be positively related to (a) rationality, (b) formalization and (c) centralization. Therefore, $\mathrm{H}_{6}$ was tested using multiple regression analysis (See Table 16, 17 \& 18).

Table 16. Summary of Multiple Regression Analysis Predicting Relationship between Entrepreneur's Innovativeness and Rationality

\begin{tabular}{llccccc}
\hline (Independent) & Variables & Adjusted R $^{2}$ & F & F sig. & $\boldsymbol{\beta}$ & p \\
\hline $1^{\text {st }}$ Step: & Environmental Dynamism & .145 & 52.98 & .000 & .331 & .000 \\
$2^{\text {nd }}$ Step: & Entrepreneur's Innovativeness & .181 & 34.91 & .000 & .204 & .000 \\
\hline
\end{tabular}

Dependent Variable: Rationality 
As exhibited in Table 16, entrepreneur's innovativeness was positively related to rationality when environmental dynamism was controlled. Explanatory rate of the model that has 2 variables is .18. Therefore, the findings support $\mathbf{H}_{6 \mathbf{a}}$.

Table 17. Summary of Multiple Regression Analysis Predicting Relationship between Entrepreneur's Innovativeness and Formalization

\begin{tabular}{llccccc}
\hline (Independent) & Variables & Adjusted R $^{2}$ & F & F sig. & $\boldsymbol{\beta}$ & p \\
\hline $1^{\text {st }}$ Step: & Environmental Dynamism & .210 & 82.75 & .000 & .428 & .000 \\
$2^{\text {nd }}$ Step: & Entrepreneur's Innovativeness & .223 & 45.18 & .000 & .130 & .013 \\
\hline
\end{tabular}

Dependent Variable: Formalization

As exhibited in Table 17, entrepreneur's innovativeness was positively related to formalization when environmental dynamism was controlled. Explanatory rate of the model that has 2 variables is 22 . Therefore, the findings support $\mathbf{H}_{6 \mathbf{b}}$.

Table 18. Summary of Multiple Regression Analysis Predicting Relationship between Entrepreneur's Innovativeness and Centralization

\begin{tabular}{llccccc}
\hline (Independent) & Variables & Adjusted R $^{2}$ & $\mathbf{F}$ & F sig. & $\boldsymbol{\beta}$ & p \\
\hline $1^{\text {st }}$ Step: & Entrepreneur's Innovativeness & .137 & 49.68 & .000 & .426 & .000 \\
$2^{\text {nd }}$ Step: & Environmental Dynamism & .171 & 32.69 & .000 & -.199 & .000 \\
\hline
\end{tabular}

Dependent Variable: Centralization

As exhibited in Table 18, entrepreneur's innovativeness was positively related to centralization when environmental dynamism was controlled. Explanatory rate of the model that has 2 variables is .27 . Therefore, the findings support $\mathbf{H}_{6 \mathbf{c}}$.

Table 19. Summary of Hierarchical Regression Analyses ${ }^{a}$

(Full Model)

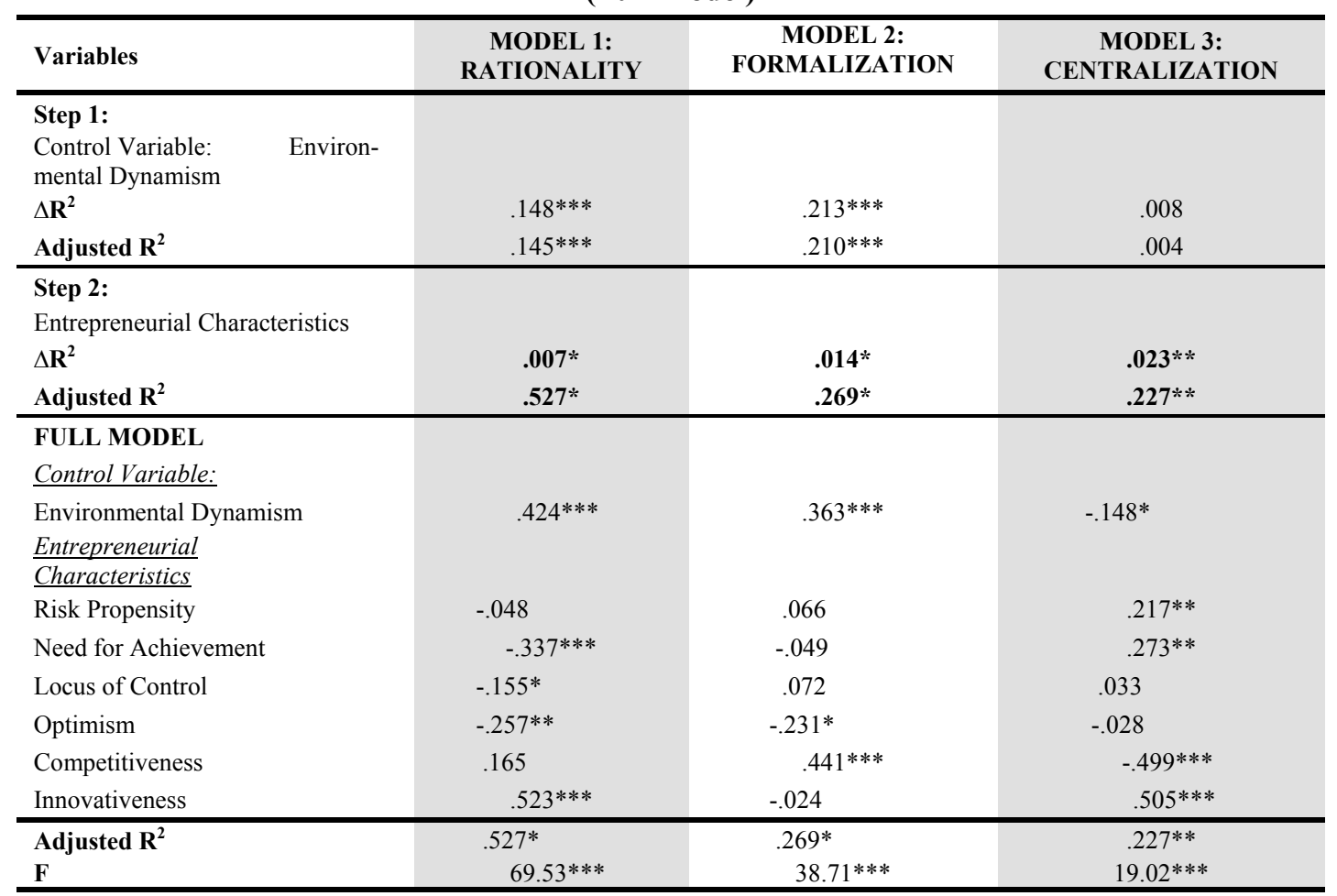

$* \mathrm{p}<0.05 * * \mathrm{p}<0.01 \quad * * * \mathrm{p}<0.001$

${ }^{\text {a }}$ Values shown in the regression models are the standardized regression coefficients. $N=308$ 
As exhibited in Table 19, entrepreneurial characteristics have significant effect on dimensions of SDM process. According to the results of hierarchical regression analyses, entrepreneurial characteristics mostly matter on rational SDM process; and formalized and centralized SDM process respectively.

\section{RESULTS AND DISCUSSION}

In this study, the effects of entrepreneurial characteristics on the dimensions of SDM process were investigated with a comprehensive model focusing on Turkish women entrepreneurs listed in The Union of Chambers and Commodity Exchanges of Turkey (TOBB)'s members in the form of local chambers of commerce and industry. As the results of analyses, women entrepreneurs' risk propensity have negative effect on their rational SDM process where as their risk propensity have positive effect on their formalized and centralized SDM process controlling environmental dynamism. By that of, risk taking women entrepreneurs make less rational decisions; do not delegate SDM authority. These findings were coherent with previous research (i.e. Brothers et al.,1998). In contrast with research, results show that risk taking women entrepreneurs make SDs formally in dynamic environments. This is some how they follow centralized configurations in decision-making and more rule formalization. Results show that women entrepreneurs with high need for achievement tend to make less rational SDs and centralize authority into the hands of themselves in dynamic environments. This result entrepreneurs with high need for achievement tend to centralize authority-is coherent with Miller \& Droge's (1986) research. After all, result show entrepreneurs with high need for achievement tent to make less rational SDs, is reverse with previous research. According to this, it can be said that women entrepreneurs in Turkey do not follow rational SDM when their need for achievement is high in dynamic environments. As the results of analyses, women entrepreneurs with internal locus of control have negative effect on their rational SDM process where as their internal locus of control have positive effect on their formalized and centralized SDM process controlling environmental dynamism. Therefore, it can be said that women entrepreneurs with internal locus of control are more likely to make less rational decisions; favor more formalized processes and centralization. Results also show that optimistic women entrepreneurs make SDs based on subjective factors instead of rational SDs but follow more rule formalization in dynamic environments. Results show that women entrepreneurs' competitiveness have negative effect on their rational SDM process where as their competitiveness have positive effect on rule formalization. According to this result, it can be suggested that women entrepreneurs' aggressive \& proactive behavior lead them to make less rational decisions. Also they tend to follow more rule formalization in dynamic environments. Nevertheless, results also show that women entrepreneurs with innovativeness tend to deal with novel and complex problems while adopting innovations. However, they make rational decisions while following rule formalization and do not delegate SDM authority. Thus far, as to these results surprisingly Turkish women entrepreneurs follow rules, procedures and standards in SDM process. Finally, results of the full model analyses show that, among all entrepreneurial characteristics, innovativeness, need for achievement, optimism, and internal locus of control matter most in rational SDM process in dynamic environments respectively. On the other hand, in rule formalization process of SDM competitiveness and optimism matter most; while in centralized process of SDM, innovativeness, competitiveness, risk propensity and need for achievement matter respectively. Furthermore, from the results of the analyses it is seen that entrepreneurial characteristics matter most in rational SDM process.

This study's theoretical contribution is examination of effects of entrepreneurial characteristics on dimensions of SDM process in a comprehensive model; proposing new variables in the model and filling this gap in the research. Furthermore, this study's practical contribution is there is lack of research that consists of stated variables in our model conducted in SMEs especially with women entrepreneurs. In this manner, women are viewed as the backbone of economic development in many developing countries. In addition according to the global entrepreneurship reports women entrepreneurs create jobs, wealth and innovations. In many of these countries the rate of growth of women creating new businesses is greater than the rate of growth for men entrepreneurs (Reynolds et al., 2002). In spite of their contribution to economic development, their freedom to lead and make strategic business decisions is greatly hampered by among other things, culture, financial status, and lack of education. In Turkey, a number of policy trends (i.e. women entrepreneurship competition cooperative with KAGÝDER (Women Entrepreneurs Association of Turkey), Garanti Bank and Ekonomist Magazine) have been made for encouraging leadership and SDM by women entrepreneurs since 2005. Thus, this study's results indicating women entrepreneurs' characteristics notably matter in their SDM process supports these arguments significance and this study's practical contribution. Additionally, women entrepreneurs in developing countries can be viewed as one of the crucial economic driver in this re- 
cession time as well as in turbulent and dynamic environment. And finally, the methodological contribution of this study is investigation of predictors of SDM process in the context of entrepreneurial characteristics and business environment in Turkey, a developing country; it shows the external validity of factors influence on SDM process which were tested in Western developed countries.

Future studies should focus on exploring this important topic in different cultures and across different size of firms. In addition, such studies should seek to employ more quantitative methods to determine the effects of entrepreneurial characteristics on dimensions of SDM process proposing different entrepreneur characteristics and environmental context variables. 


\section{REFERENCES}

Achrol, R. S. and Stern, L. W. (1988). Environmental Determinants of Decision-Making Uncertainty in Marketing Channels, Journal of Marketing Research, 25: 36-50.

Bakker, R. M., Curpeu, P. L. and Vermeulen, P. (2007). Cognitive Factors in Entrepreneurial Strategic Decision Making, Cognition, Brain \& Behavior, 11(1): 195-219.

Balta, M. E., Woods, A. and Dickson, K. (2010). The Influence of Boards of Directors' Characteristics on Strategic Decision-Making: Evidence from Greek Companies, Journal of Applied Business Research, 26(3): 57-68.

Bantel, K.A. and Jackson, S. E. (1989). Top Management and Innovation in Banking: Does the Composition of the Top Team make a Difference?, Strategic Management Journal, 10: 107-124.

Bazerman, M. (1999). Smart Money Decisions, New York: Wiley.

Bentler, P. M. (1990). Comparative Fit Indexes in Structural Models, Psychological Bulletin, 107: 238-246.

Bourgeois, L. J. III and Eisenhardt, K. M. (1998). Strategic Decision Processes in High Velocity Environments: Four Cases in The Microcomputer Industry, Management Science, 34(7): 816-835.

Brandstatter, H. (2010). Personality Aspects of Entrepreneurship: A Look at Five Meta-Analyses, Personality and Individual Differences, In Press.

Brockhaus, R. (1980). Risk Taking Propensity of Entrepreneurs, The Academy of Management Journal, 23(3): 509-520.

Brouthers, K., Andriessen, F. and Nicolaes, I. (1998). Driving Blind: Strategic Decision-Making in Small Companies, Long Range Planning, 31(1): 130-138.

Browne, M. W. and Cudeck, R. (1992). Alternative Ways of Assessing Model Fit, Sociological Methods and Research, 21: 230-258.

Byers, T. and Slack, T. (2001). Strategic Decision-Making in Small Businesses within the Leisure Industry, Journal of Leisure Research, 33(2): 121-136.

Carver, C. (1997). The Internal-External Scale Confounds Internal Locus of Control with Expectancies of Positive Outcomes, Personality and Social Pscychology Bulletin, 23(6): 580-585.

Child, J. (1972). Organizational Structure, Environment and Performance: The Role of Strategic Choice, Sociology, 6: 1-22.

Cohen, J., and Cohen, P.1983 Applied Multiple Regression/Correlation Analysis for the Behavioral Sciences, Second Edition, Hillsdale, NJ: Lawrence Erlbaum.

Connor, K. M. and Davidson, J. R. T. (2003). Development of a New Resilience Scale:The ConnorDavidson Resilience Scale (CD-RISC), Depression and Anxiety, 18: 76-82.

Cooper, A., C. Wood and W. Dunkelberg (1988). Entrepreneur's Perceived Chances for Success, Journal of Business Venturing, 3(2): 97-108.

Dean, J. W. and Sharfman, M. P. (1996). Does Decision Process Matter? A Study of Strategic Decision-Making Effectiveness, The Academy of Management Journal, 39(2): 368-396.

Dean, J. W. Jr, Sharfman, M. P. and Ford, C. A. (1993). The Relationship of Procedural Rationality and Political Behavior in Strategic Decision-Making, Decision Sciences, 24(6): 1069-1083.

Dess, G. G., \& Beard, D. W. (1984). Dimensions of Organizational Task Environments, Administrative Science Quarterly, 29(1): 52-73.

Drucker, P. (1985). The Discipline of Innovation, Harvard Business Review, 63(3): 67-72.

Eisenhardt, K. M. (1989). Making Fast Strategic Decisions in High Velocity Environments, The Academy of Management Journal, 32(3): 543-576.

Eisenhardt, K. M. and Schoonhoven, C. B. (1990). Organizational Growth: Linking Founding Team, Strategy, Environment, and Growth among U.S. Semiconductor Ventures, 1978-1988, Administrative Science Quarterly, 33: 504-529. 
Eisenhardt, K. M., \& Zbaracki, M. J. (1992). Strategic Decision Making, Strategic Management Journal, 13: 17-37.

Eysenck, H. J. and Wilson, G. (1975). Know Your Own Personality. UK: Penguin.

Forbes, D. P. (2007). Reconsidering the Strategic Implications of Decision Comprehensiveness, The Academy of Management Review, 32(2): 361-376.

Fredrickson, J. W. (1984). The Comprehensiveness of Strategic Decision Process: Extension, Observations, Future Directions, The Academy of Management Journal, 27(3): 445-466.

Frese, M., Gelderen, M. V. and Ombach, M. (2000). How to Plan As a Small Scale Business Owner: Psychological Process Characteristics of Action Strategies and Success, Journal of Small Business Management, 38: 1-18.

Gibcus, P., van Hoesel, P .H. M. (2004). Transforming an Idea into a Strategic Decision in SMEs: The Underlying Decision-Making Process, Scales Research Report H200311, EIM Business \& Policy Research.

Gibcus, P., Vermeulen, P. A. M. and Jong, J. P. J. (2006). Strategic Decision Making in Small Firms: Towards a Taxonomy of Entrepreneurial Decision-Makers, SCALES-paper N200511, EIM Business \& Policy Research.

Gupta, A.K. 1984. Contingency Linkages between Strategy and General Manager Characteristics: A Conceptual Examination, The Academy of Management Review, 9(3): 399-412.

Hage, J. (1980). Theories of Organization. New York: John Wiley.

Hair, J. F., Black, W.C., Babin, B. J., Anderson, R. E. and Tatham, R. L. (2006). Multivariate Data Analysis, Sixth Edition, U.S.A.: Pearson Prentice Hall,Inc.

Haleblian, J. and Finkelstein, S. (1993). Top Management Team Size, CEO Dominance, and Firm Performance: The Moderating Roles of Environmental Turbulence and Discretion, Academy of Management Journal, 36(4): 844-863.

Hambrick, D. C. and Mason, P. (1984). Upper Echelons: The Organization as a Reflection of its Top Managers, The Academy of Management Review, 9: 193-206.

Hannan, M. T. and Freeman, J. H. (1977). The Population Ecology of Organizations, American Journal of Sociology, 82: 929-964.

Heckert, T. M., Cuneı, G., Hannah, A. P., Adams, P. J., Droste, H. E., Mueller, M. A., Wallis, H. A., Griffin, C. M., and Roberts, L. L. (1999). Creation of a New Needs Assessment Questionnaire, Journal of Social Behavior and Personality, 15(1): 121-136.

Hickson, D. J., Butler, R. J., Cray, D., Mallory, G. R. and Wilson, D. C. (1986). Top Decisions: Strategic Decision-Making in Organizations, Oxford: Basil Blackwell.

Hitt, M. and Tyler, B. (1991). Strategic Decision Models: Integrating Different Perspectives, Strategic Management Journal, 12(5): 327-351.

Hough, J. R. and White, M. A. (2003). Environmental Dynamism and Strategic Decision-Making Rationality: An Examination at the Decision Level, Strategic Management Journal, 24: 481-489.

Hurt, H. T., Joseph, K., and Cook, C. D. (1977). Scales for the Measurement of Innovativeness, $\boldsymbol{H u}$ man Communication Research, 4: 58-65.

Ivanova, E. and Gibcus, P. (2003). The Decision-Making Entrepreneur: Literature Review, SCALESpaper N200219, EIM Business \& Policy Research.

Jackson, D. N. (1977). Reliability of the Jackson Personality Inventory, Psychological Reports, 40: 613-614.

Ji, J. (2010). Strategic Decision Making Process Characteristics, Confucian Values, and their Effects on International Entry Mode Decisions: A Study of Chinese Private Firms, Doctorate Dissertation, University of Glasgow.

Jöreskog, R. D. and Sörbom, D. (1993). LISREL 8: Structural Equation Modeling with the SIMPLIS $^{T M}$ Command Language, Chicago: Scientific Software International. 
Judge, W. Q. and Miller, A. (1991). Antecedents Outcomes of Decision Speed in Different Environmental Context, The Academy of Management Journal, 34(2): 449-463.

Khandwalla, P. N. (1977). The Design of Organizations. New York: Harcourt Brace Jovanovich.

Khatri, N. and NG, H. A. (1997). Role of Intuition in Strategic Decision Making, Nanyang Business School Working Papers.

Lewin, A. Y. and Stephens, C. U. (1994). CEO Attributes as Determinants of Organization Design: An Integrated Model, Organization Studies, 15(2): 183-212.

Liang, C. and Dunn, P. (2008). Are Entrepreneurs Optimistic, Realistic, Both or Fuzzy? Relationship between Entrepreneurial Traits and Entrepreneurial Learning, Academy of Entrepreneurship Journal, 14(1): 51-73.

Lieberson, S. and O'Connor, J. F. (1972). Leadership and Organizational Performance: A Study of Large Corporations, American Sociological Review, 37: 117-130.

Low, M. and MacMillan, I. (1988). Entrepreneurship: Past Research and Future Challenges, Journal of Management, 14(2): 139-161.

Lyles, M. A. (1987). Defining Strategic Problems: Subjective Criteria of Executives, Organization Studies, 8(3): 263-280.

Lyles, M. A. and Mitroff, J. I. (1980). Organizational Problem Formulation: An Empirical Study, Administrative Science Quarterly, 25: 102-119.

Lyon, D., Lumpkin, G. and Dess, G. (2000). Enhancing Entrepreneurial Orientation Research: Operationalizing and Measuring a Key Strategic Decision-Making Process, Journal of Management, 26 (5): 1055-1085.

Marcati, A., Guido, G., and Peluso, A. M. (2008). The Role of SME Entrepreneurs' Innovativeness and Personality in the Adoption of Innovations, Research Policy, 37: 1579-1590.

March, J. G. and Shapira, Z. (1982). "Behavioral Decision Theory and Organizational Decision Theory”, in Ungson, G. and Braunstein, D. (Eds), Decision Making, Boston: Kent Publishing Co., 92 -110 .

McCarthy, A., Schoorman, F. and Cooper, A. (1993). Reinvestment Decisions By Entrepreneurs: Rational Decision-Making or Escalation of Commitment?, Journal of Business Venturing, 8: 9-24.

McClelland, D. (1961). The Achieving Society, New York:Van Nostrand.

McCroskey, J. C. (2006). Communication research measures: Individual innovativeness. http:// www.jamescmccroskey.com/measures/innovation.ht (22.11.2010)

McDonald, M., Spears, M. C. and Parker, D. F. (2004). Strategic Management: Does Personality Make a Difference?, Academy of Strategic Management Journal, 3: 37-45.

Meertens, R. M. and Lion, R.. (2008). Measuring an Individual's Tendency to Take Risks: The Risk Propensity Scale, Journal of Applied Social Psychology, 38(6): 1506-1520.

Miller, D. and Friesen, P. H. (1983). Strategy-Making and Environment: The Third Link, Strategic Management Journal, 4(3): 221-235.

Miller, D. (1987). Making and Structure: Analysis and Implications for Performance The Academy of Management Journal, 30(1): 7-32.

Miller, D. and Droge, C. (1986). Psychological and Traditional Determinants of Structure, Administrative Science Quarterly, 31: 539-60.

Miller, D., Droge, C. and Toulouse, J. M. (1988). Strategic Process and Content as Mediators between Organizational Context and Structure, The Academy of Management Journal, 31(3): 544569.

Miller, D. and Toulouse, J. M. (1986). Chief Executive Personality and Corporate Strategy and Structure in Small Firms, Management Science, 1389-1409.

Miller, C. C., Ogilvie, D., and Glick, W. H. (2006). Assessing the External Environment: An Enrichment of Ten Archival Traditions, Research Methodology in Strategy and Management, 3: 97-122. 
Mueller, G. C., Mone, M. A., and Barker, V. L. (2007). Formal Strategic Analyses and Organizational Performance: Decomposing the Rational Model, Organization Studies, 28(6): 853-883.

Mullins, J. and D. Forlani. (2000). Perceived Risks and Choices in Entrepreneurs' New Venture Decisions, Journal of Business Venturing, 15: 305-322.

Nahavandi, A. and Malekzadeh, A. R. (1993). Leader Style in Strategy and Organizational Performance: An Integrative Framework, Journal of Management Studies, 30(3): 405-425.

Norburn, D. and Birley, B. (1988). The Top Management Team and Corporate Performance, Strategic Management Journal, 9: 225-237.

Nwachukwu, O. (1995). CEO Locus of Control, Strategic Planning, Differentiation, and Small Business Performance: A Test of Path Analytic Model, Journal of Applied Business, 11(4): 9-14.

Palich, L. and D. Bagby (1995). Using Cognitive Theory to Explain Entrepreneurial Risk Taking: Challenging Conventional Wisdom, Journal of Business Venturing, 10: 425-438.

Papadakis, V. M. (2006). Do CEOs Shape the Process of Making Strategic Decisions? Evidence from Greece, Management Decision, 44(3): 367-394.

Papadakis, V. M. and Barwise, P. (1996). Top Management Characteristics and Strategic Decision Processes, Centre for Marketing Working Paper, No.96-101:1-36.

Papadakis, V. M. and Barwise, P. (2002). How Much do CEOs and Top Managers Matter in Strategic Decision-Making?, British Journal of Management, 13: 83-95.

Papadakis, V. M., Lioukas, S. and Chambers, D. (1998). Strategic Decision Making Processes: The Role of Management and Context, Strategic Management Journal, 19: 115-147.

Rajagopalan, N., Rasheed, A. M. A. and Datta, D. K. (1993). Strategic Decision Processes: Critical Review and Future Directions, Journal of Management, 19(2): 349-384.

Pearce Ii, J. A., and Robbins, D. K. 1987. The Impact of Grand Strategy and Planning Formality on Financial Performance, Strategic Management Journal, 8(2): 125-134.

Pfeffer, J. (1981). Power in Organizations, Marshfield, Mass.:Pitman Publishing.

Reynolds, P. D., Bygrave, W., Autio, E., Cox, L. W. and Hay, M. (2002). Global Entrepreneurship Monitor (GEM): 2002 Executive Report, Kauffman Center for Entrepreneurial Leadership at the Ewing Marion Kauffman Foundation, Kansas City, MO.

Rice, G. H. and Hamilton, R. E. (1979). Decision Theory and the Small Businessman, American Journal of Small Business, 4(1): 7-15.

Robinson, J. R. B., Pearce Ii, J. A., Vozikis, G. S., and Mescon, T. S. (1984). The Relationship between Stage of Development and Small Firm Planning and Performance, Journal of Small Business Management, 22(2): 4552.

Robinson, J. R. B., and Pearce Ii, J. A. (1983). The Impact of Formalized Strategic Planning on Financial Performance in Small Organizations, Strategic Management Journal, 4(3): 197-207.

Rotter, J. (1966). Generalized Expectancies for Internal Versus External Control of Reinforcements, Psychological Monographs, 80: 1-28.

Sashkin, M. (1988). “The visionary leader”, in Conger, J.A. and Kanungo, R.N. (Eds), Charismatic Leadership, CA: Jossey-Bass, 122-160.

Scheier. M. F., Carver, C. S. (1985). Optimism, Coping, and Health: Assessment and Implications of Generalized Outcome Expectancies, Health Psychology, 4(3):219-247.

Scheier. M. F., Carver, C. S. and Bridges, M. W. (1994). Distinguishing Optimism from Neuroticism (and Trait Anxiety, Self-Mastery, and Self-Esteem): A Re-evaluation of the Life Orientation Test, Journal of Personality and Social Psychology, 67(6): 1063-1078.

Schere, J. (1982). Tolerance and Ambiguity as a Discriminating Variable between Entrepreneurs and Managers, Proceeding of The Academy of Management Conference, New York, 404-408.

Schoemaker, P. J. H. (1993). Strategic Decisions in Organizations: Rational and Behavioural Views, Journal of Management Studies, 30(1): 107-129.

Schumpeter, J. (1954). History of Economic Analysis, New York: Oxford University Press. 
Shapero, A. and L. Sokol (1982). The Social Dimensions of Entrepreneurship, Encyclopedia of Entrepreneurship, Englewood Cliffs, NJ: Prentice-Hall.

Sharfman, M. P., and Dean, J. J. W. (1991). Conceptualizing and Measuring the Organizational Environment: A Multidimensional Approach, Journal of Management, 17(4): 681- 700.

Smith, K. G., Smith, K. A., Olian, J. D., Sims, H. P., O’Bannon, D. P. and Scully, J. A. (1994). Top Management Team Demography and Process: The Role of Social Integration and Communication, Administrative Science Quarterly, 39: 412-438.

Spector, P. (1992). Behavior in Organizations as a Function of Locus of Control, Psychological Bulletin, 91: 482-497.

Steers, R. M. and Braunstein, D. N. (1976). A Behaviorally-Based Measure of Manifest Needs in Work Settings, Journal of Vocational Behavior, 9: 251-266.

Steiger, J. H. (1990). Structural Model Evaluation and Modification: An Interval Estimation Approach, Multivariate Behavioral Research, 25: 173-180.

Stein, J. (1980). Contextual Influence on Strategic Decision Methods. Ph.D. Dissertation, University of Pennsylvania.

Straub, D. W. (1989). Validating Instruments in MIS Research, MIS Quarterly, 13(2):147-1699.

Taylor, R.N. and Dunnette, M.D. (1974). Relative Contribution of Decision-Maker Attributes to Decision Processes, Organizational Behavior and Human Performance, 12, 286-298.

Timmons, J. (1990). New Venture Creation: Entrepreneurship in the 1990's, Homewood, IL, Irwin.

Triandis, H. C. and Gelfand, M. J. (1998). Converging Measurement of Horizontal and Vertical Individualism and Collectivism, Journal of Personality and Social Psychology, 74(1): 118-128.

Vermeulen, P. A. M. \& Curpeu, P. L. (2008). Entrepreneurial Strategic Decision Making: A Cognitive Perspective, UK: Edward Elgar Publishing.

Wally, S. and Baum, J. R. (1994). Personal and Structural Determinants of the Pace of Strategic Decision Making, The Academy of Management Journal, 37(4): 932-956.

Wilson, D. C. (2003). Strategy as Decision Making. In S. Cummings, \& D. C. Wilson (Eds.), Images of Strategy: 383-410. Oxford: Blackwell Publishing.

Mueller, G. C., Mone, M. A., and Barker, V. L. (2007). Formal Strategic Analyses and Organizational Performance: Decomposing the Rational Model, Organization Studies, 28(6): 853-883.

Mullins, J. and D. Forlani. (2000). Perceived Risks and Choices in Entrepreneurs' New Venture Decisions, Journal of Business Venturing, 15: 305-322.

Nahavandi, A. and Malekzadeh, A. R. (1993). Leader Style in Strategy and Organizational Performance: An Integrative Framework, Journal of Management Studies, 30(3): 405-425.

Norburn, D. and Birley, B. (1988). The Top Management Team and Corporate Performance, Strategic Management Journal, 9: 225-237.

Nwachukwu, O. (1995). CEO Locus of Control, Strategic Planning, Differentiation, and Small Business Performance: A Test of Path Analytic Model, Journal of Applied Business, 11(4): 9-14.

Palich, L. and D. Bagby (1995). Using Cognitive Theory to Explain Entrepreneurial Risk Taking: Challenging Conventional Wisdom, Journal of Business Venturing, 10: 425-438.

Papadakis, V. M. (2006). Do CEOs Shape the Process of Making Strategic Decisions? Evidence from Greece, Management Decision, 44(3): 367-394.

Papadakis, V. M. and Barwise, P. (1996). Top Management Characteristics and Strategic Decision Processes, Centre for Marketing Working Paper, No.96-101:1-36.

Papadakis, V. M. and Barwise, P. (2002). How Much do CEOs and Top Managers Matter in Strategic Decision-Making?, British Journal of Management, 13: 83-95.

Papadakis, V. M., Lioukas, S. and Chambers, D. (1998). Strategic Decision Making Processes: The Role of Management and Context, Strategic Management Journal, 19: 115-147. 
Rajagopalan, N., Rasheed, A. M. A. and Datta, D. K. (1993). Strategic Decision Processes: Critical Review and Future Directions, Journal of Management, 19(2): 349-384.

Pearce Ii, J. A., and Robbins, D. K. 1987. The Impact of Grand Strategy and Planning Formality on Financial Performance, Strategic Management Journal, 8(2): 125-134.

Pfeffer, J. (1981). Power in Organizations, Marshfield, Mass.:Pitman Publishing.

Reynolds, P. D., Bygrave, W., Autio, E., Cox, L. W. and Hay, M. (2002). Global Entrepreneurship Monitor (GEM): 2002 Executive Report, Kauffman Center for Entrepreneurial Leadership at the Ewing Marion Kauffman Foundation, Kansas City, MO.

Rice, G. H. and Hamilton, R. E. (1979). Decision Theory and the Small Businessman, American Journal of Small Business, 4(1): 7-15.

Robinson, J. R. B., Pearce Ii, J. A., Vozikis, G. S., and Mescon, T. S. (1984). The Relationship between Stage of Development and Small Firm Planning and Performance, Journal of Small Business Management, 22(2): 4552.

Robinson, J. R. B., and Pearce Ii, J. A. (1983). The Impact of Formalized Strategic Planning on Financial Performance in Small Organizations, Strategic Management Journal, 4(3): 197-207.

Rotter, J. (1966). Generalized Expectancies for Internal Versus External Control of Reinforcements, Psychological Monographs, 80: 1-28.

Sashkin, M. (1988). “The visionary leader”, in Conger, J.A. and Kanungo, R.N. (Eds), Charismatic Leadership, CA: Jossey-Bass, 122-160.

Scheier. M. F., Carver, C. S. (1985). Optimism, Coping, and Health: Assessment and Implications of Generalized Outcome Expectancies, Health Psychology, 4(3):219-247.

Scheier. M. F., Carver, C. S. and Bridges, M. W. (1994). Distinguishing Optimism from Neuroticism (and Trait Anxiety, Self-Mastery, and Self-Esteem): A Re-evaluation of the Life Orientation Test, Journal of Personality and Social Psychology, 67(6): 1063-1078.

Schere, J. (1982). Tolerance and Ambiguity as a Discriminating Variable between Entrepreneurs and Managers, Proceeding of The Academy of Management Conference, New York, 404-408.

Schoemaker, P. J. H. (1993). Strategic Decisions in Organizations: Rational and Behavioural Views, Journal of Management Studies, 30(1): 107-129.

Schumpeter, J. (1954). History of Economic Analysis, New York: Oxford University Press.

Shapero, A. and L. Sokol (1982). The Social Dimensions of Entrepreneurship, Encyclopedia of Entrepreneurship, Englewood Cliffs, NJ: Prentice-Hall.

Sharfman, M. P., and Dean, J. J. W. (1991). Conceptualizing and Measuring the Organizational Environment: A Multidimensional Approach, Journal of Management, 17(4): 681- 700.

Smith, K. G., Smith, K. A., Olian, J. D., Sims, H. P., O’Bannon, D. P. and Scully, J. A. (1994). Top Management Team Demography and Process: The Role of Social Integration and Communication, Administrative Science Quarterly, 39: 412-438.

Spector, P. (1992). Behavior in Organizations as a Function of Locus of Control, Psychological Bulletin, 91: 482-497.

Steers, R. M. and Braunstein, D. N. (1976). A Behaviorally-Based Measure of Manifest Needs in Work Settings, Journal of Vocational Behavior, 9: 251-266.

Steiger, J. H. (1990). Structural Model Evaluation and Modification: An Interval Estimation Approach, Multivariate Behavioral Research, 25: 173-180.

Stein, J. (1980). Contextual Influence on Strategic Decision Methods. Ph.D. Dissertation, University of Pennsylvania.

Straub, D. W. (1989). Validating Instruments in MIS Research, MIS Quarterly, 13(2):147-1699.

Taylor, R.N. and Dunnette, M.D. (1974). Relative Contribution of Decision-Maker Attributes to Decision Processes, Organizational Behavior and Human Performance, 12, 286-298.

Timmons, J. (1990). New Venture Creation: Entrepreneurship in the 1990's, Homewood, IL, Irwin. 
Triandis, H. C. and Gelfand, M. J. (1998). Converging Measurement of Horizontal and Vertical Individualism and Collectivism, Journal of Personality and Social Psychology, 74(1): 118-128.

Vermeulen, P. A. M. \& Curpeu, P. L. (2008). Entrepreneurial Strategic Decision Making: A Cognitive Perspective, UK: Edward Elgar Publishing.

Wally, S. and Baum, J. R. (1994). Personal and Structural Determinants of the Pace of Strategic Decision Making, The Academy of Management Journal, 37(4): 932-956.

Wilson, D. C. (2003). Strategy as Decision Making. In S. Cummings, \& D. C. Wilson (Eds.), Images of Strategy: 383-410. Oxford: Blackwell Publishing. 